\title{
Prognostic value of mean platelet volume and neutrophil to lymphocyte ratio in patients with Crimean-Congo Hemorrhagic Fever
}

\author{
Ayşe Ertürk¹, Erkan Cüre², Emine Parlak³ ${ }^{3}$ Medine Cumhur Cüre ${ }^{4}$, Süleyman Yüce ${ }^{2}$, Zulal Özkurt ${ }^{3}$ \\ ${ }^{1}$ Recep Tayyip Erdogan University, School of Medicine, Department of Infectious Disease, Rize, Turkey \\ ${ }^{2}$ Recep Tayyip Erdogan University, School of Medicine, Department of Internal Medicine, Rize, Turkey \\ ${ }^{3}$ Ataturk University, School of Medicine, Department of Infectious Disease, Erzurum, Turkey \\ ${ }^{4}$ Recep Tayyip Erdogan University, School of Medicine, Department of Biochemistry, Rize, Turkey
}

\begin{abstract}
Objective: Crimean-Congo hemorrhagic fever (CCHF) virus, a Nairovirus within the family Bunyaviridae, causes severe disease in humans. Pancytopenia, organ failures and disseminated intravascular coagulation may occur as a result of CCHF infection. The aim of this study was to determine whether there is a change in the mean platelet volume (MPV), neutrophil-to-lymphocyte ratio (NLR) and platelet-to-lymphocyte ratio (PLR), and whether these might be predictors for the duration of hospitalization.
\end{abstract}

Methods: A total of $50 \mathrm{CCHF}$ patients ( $27 \mathrm{M}$ and $23 \mathrm{~F}$ ) and a similar age group of 47 healthy individuals ( $27 \mathrm{M}$ and 20 F) were included in the study. Hematologic and biochemical tests inclusive of C-reactive protein were conducted on patients and controls. To determine the independent predictors of the duration of hospitalization, a multivariate logistic regression analysis was performed.

Results: The MPV was higher in patients than that of the controls [8.4 (min/max 6.4-9.4) fL vs. 7.0 (min/max 6.0-8.7) $\mathrm{fL}, \mathrm{p}<0.001]$. The NLR and PLR were similar in both groups. The predictors of the length of hospitalization included decreased white blood (WBC) cell and platelet counts $(p<0.001$ and $p=0.002$, respectively), together with elevated prothrombin time (PT) $(p=0.013)$ creatinine $(p=0.033)$ and glucose levels $(p=0.044)$

Conclusion: The MPV was higher in patients but NLR and PLR were similar in both groups. The MPV, NLR and PLR did not serve as predictors of hospitalization length. However, elevation of PT, creatinine, glucose, along with decreased WBC and platelets counts were found to be predictors of hospitalization period. J Microbiol Infect Dis 2015;5(2): 51-56

Key words: Crimean-Congo hemorrhagic fever; mean platelet volume; neutrophil-to-lymphocyte ratio; platelet-tolymphocyte ratio; hospitalization period.

\section{Kırım-Kongo Hemorajik Ateşli Hastalarda Ortalama Trombosit Hacmi ve Nötrofil/Lenfosit Oranının Prognostik Değeri}

\section{ÖZET}

Amaç: Kırım-Kongo Kanamalı Ateşi (KKHA) virüsü, Bunyaviridae ailesine üye Nairovirus olup insanlarda ciddi hastalığa neden olur. KKKA enfeksiyonunda pansitopeni, organ yetersizliği ve yaygın damar-içi pıhtılaşma ortaya çıkabilir. Bu çaIışmanın amacı, ortalama trombosit hacmi (MPV), nötrofil-lenfosit oranı (NLR) ve trombosit-lenfosit oranı (PLR)'nda bir değişiklik olup olmadığını ve bu parametrelerin hastanede kalış süresi için prediktör olup olamayacağını belirlemektir.

Yöntem: Toplam 50 KKHA hastalığı bulunan (27 M ve 23 F) ve benzer yaş grubunda toplam 47 (27 M ve 20 F) sağlıklı birey çalışmaya alındı. Hematolojik ve biyokimyasal testleri ile C-reaktif protein (CRP), hasta ve kontrollerde çalışıldı. Hastanede kalış süresi üzerinde bağımsız prediktörleri belirlemek amacıyla çok değişkenli lojistik regresyon analizi yapıldı.

Bulgular: MPV, hastalarda kontrollerden daha yüksek [8.4 (min / maks 6,4-9,4) fL vs 7.0 (min/maks 6,0-8,7) fL, p <0.001] idi. NLR ve PLR her iki grupta benzerdi. Hastanede kalış süresi prediktörleri: düşük beyaz kan hücreleri (WBC) ve trombosit sayısı ( $p<0.001$ ve $p=0.002$ sırasıyla), bunlar yanı sıra uzamış protrombin zamanı (PT) $(p=0.013)$, yüksek kreatinin $(p=0.033)$ ve glukoz $(p=0.044)$ düzeyleri olarak saptandı.

Sonuç: MPV hasta grubunda daha yüksek olup NLR ve PLR oranları kontrol grubu ile benzerdi. MPV, NLR ve PLR hastanede kalış uzunluğu belirleyicisi olarak tespit edilmedi. Ancak, azalmış lökosit ve trombosit sayımı ile birlikte uzamış PT, artmış kreatinin ve glukoz düzeyleri, hospitalizasyon süresini predikte ettiği bulundu.

Anahtar kelimeler: Kırım-Kongo Kanamalı Ateşi; ortalama trombosit hacmi; nötrofil/lenfosit oranı; trombosit/lenfosit oranı; hastanede yatış süresi. 


\section{INTRODUCTION}

Crimean-Congo hemorrhagic fever (CCHF) virus (CCHFV) belongs to the genus Nairovirus within the Bunyaviridae family. The virus can cause severe infection in humans. Hemorrhagic lesions, pancytopenia, organ failure, and disseminated intravascular coagulation may occur as a result of CCHFV infection. ${ }^{1}$ Impairment of vascular endothelial cell function may also lead to increased vascular permeability and hemorrhages. ${ }^{2}$ Previous studies suggest that a combination of high levels of regulatory cytokines (e.g. IL-10), which inhibit cell-mediated immunity by down regulating IL-12 expression, with high levels of pro-inflammatory cytokines, e.g. interferon gamma (IFN- $\mathrm{y}$ ) and tumor necrosis factor alpha (TNF- $\alpha$ ), might play an important role in the pathogenesis of CCHF. ${ }^{3}$ Platelet size correlates with platelet activity and may be assessed by measuring the mean platelet volume (MPV) using routine blood counts by automated hemogram. Larger platelets have more granules and higher thromboxane A2 levels, aggregate more rapidly with collagen, and express more glycoprotein Ib and Ilb/IIla receptors than smaller platelets. ${ }^{4}$ Substances released from thrombocytes are important mediators of coagulation, inflammation, thrombosis, and atherosclerosis. A number of studies have found that MPV levels are associated with arterial or venous occlusive disorders. ${ }^{5}$ Other studies have reported that MPV is a prognostic factor in the mortality and the length of hospitalization of patients with CCHF. ${ }^{6}$ The neutrophil-to-lymphocyte ratio (NLR) and the platelet-tolymphocyte ratio (PLR) are accepted as good predictors of systemic infection. ${ }^{7,8}$ Both NLR and PLR have been approved as prognostic and predictive factors in a number of diseases. In CCHF, hemophagocytic lymphohistiocytosis occurs because of an increase in proinflammatory cytokines, which increase hemophagocytic macrophage proliferation and activation in the reticuloendothelial system. ${ }^{9}$ As a result, the numbers of leucocytes and platelets decrease rapidly.

This study evaluates changes in MPV levels, and NRL and PLR ratios in patients that have recovered from non-mortal CCHF in order to determine whether these factors might be predictors for the duration of hospitalization.

\section{METHODS}

Patients and controls: This study was performed according to the guidelines of the Helsinki Declaration and was approved by the local ethics com- mittees. Fifty patients diagnosed with $\mathrm{CCHF}(27 \mathrm{M}$, $23 \mathrm{~F}$ ) who were admitted to the Infectious Disease Clinic (Ataturk University Medical School Hospital), were enrolled in the study. Patients who sustained tick bites were monitored daily for progress. Blood samples were obtained and sent to Refik Saydam Health Institute (CCHF Reference Center within the Virology Reference Laboratory) in Ankara according to cold chain rules. At that center, the blood samples were checked for CCHF nucleic acids by real-time reverse transcriptase polymerase chain reaction (RT-PCR). All patients were classified as "mildly severe CCHF patients" according to the criteria of Swanepoel et al. ${ }^{10}$ The control group consisted of 47 healthy subjects ( $20 \mathrm{M}$ and $27 \mathrm{~F}$ ). The subjects in the control group had not been exposed to tick bites and had no history of contact with any of the CCHF patients. The study excluded patients and control subjects with a history of diabetes, hypertension, hyperlipidemia, coronary artery disease, chronic obstructive pulmonary disease, cirrhosis, portal hypertension, hematological disorders, and malignancies. All participants were non-smokers, with no history of alcohol or substance use.

\section{Hospitalization Period}

The first day was when clinical diagnosis of the condition was made. The recovery day was taken to be the date in which all clinical symptoms disappeared and the patients were discharged. Recovery was also confirmed by laboratory tests, which demonstrated normal values for each parameter measured, and by the absence of viral RNA by RT-PCR. The length of hospital stay was the period from admission to discharge.

\section{Laboratory tests}

Biochemical tests for fasting plasma glucose (FPG), aspartate transaminase (AST), alanine aminotransferase (ALT), gamma glutamyl transferase (GGT), blood urea nitrogen (BUN), creatinine, lactate dehydrogenase $(\mathrm{LDH})$, bilirubin and creatine phosphokinase (CPK) were performed using photometric assays using the Abbott Architect $(\mathrm{c} 16000$ analyzer (Abbott Diagnostics, Abbott Park, IL, USA). Hematological tests for $\mathrm{Hb}$, platelets, white blood cell counts (WBC), and MPV were performed using the Abbott Cell-Dyn® Ruby analyzer (Abbott Diagnostics, IL, USA). The C-reactive protein (CRP) test was performed using the nephelometric method in the Coulter Image 800 autoanalyser (Beckman Coulter, CA, USA). Coagulation parameters were 
measured using a Diagnostica Stago kit in a STA Compact Coagulation analyzer (MA, USA).

\section{Statistical Analysis}

The normal distribution of data was determined using a Kolmogorov-Smirnov test. An independent sample t-test was performed for normal distribution parameters (age, glucose, ESR, neutrophil, lymphocyte) and Mann-Whitney U test was performed for non-normal distribution parameters (all remaining tests). Pearson's correlation test and Stepwise multivariate (MVA) logistic regression analyses were used to apply MPV and other parameters.

\section{RESULTS}

The MPV of the CCHF group [8.4 ( $\min / \max 6.4-9.4)$ $\mathrm{fL}]$ higher than that of the control group $[7.0(\mathrm{~min} /$ max 6.0-8.7), $p<0.001]$, which was statistically significant. The WBC counts $[2.7(\mathrm{~min} / \mathrm{max} 0.9-5.1)$ $\mathrm{x} 109 / \mathrm{L}]$ and platelet numbers $[77(\mathrm{~min} / \max 10-220)$ $x 109 / L]$ of the CCHF group were lower than those of the control group [7.0 $(\mathrm{min} / \mathrm{max} 5.0-14.0) \times 109 / \mathrm{L}$ for WBC, $\mathrm{p}<0.001$; and $245(\mathrm{~min} / \mathrm{max} 188-455) \times 109 / \mathrm{L}$ for platelet, $p<0.001$, respectively]. The mean hospitalization duration of the patients with $\mathrm{CCHF}$ was $13.2 \pm 2.5$ days. Table 1 shows the demographic features and hemogram results of the patients and controls. The FPG $(p=0.013)$, BUN $(p=0.022)$, creatinine $(p<0.001)$, AST $(p<0.001)$, ALT $(p<$ $0.001)$, LDH $(p<0.001)$, CPK $(p<0.001)$, total bilirubin $(p<0.001)$, prothrombin time (PT) $(p<0.001)$ levels and the activated partial thromboplastin time (aPTT) $(p<0.001)$ of the patients were statistically significantly higher than those of the control group (Table 2).

Table 1. The main characteristics and hematologic parameters of patients and controls

\begin{tabular}{lccc}
\hline & CCHF & Control & p value \\
\hline Age (years) & $45.2 \pm 15.8$ & $40.7 \pm 10.2$ & 0.112 \\
Gender M/F (n) & $27 / 23$ & $20 / 27$ & 0.178 \\
WBC (x10\%/L) & $2.7(0.9-5.1)$ & $7.0(5.0-14.0)$ & 0.001 \\
Hb (g/dL) & $14.0(8.0-17.0)$ & $13.0(10.0-18.0)$ & 0.076 \\
MPV (fL) & $8.4(6.4-9.4)$ & $7.0(6.0-8.7)$ & 0.001 \\
Platelet (x10\%/L) & $77(10-220)$ & $245(188-455)$ & 0.001 \\
Neutrophils (\%) & $53.3 \pm 15.5$ & $58.9 \pm 11.9$ & 0.081 \\
Lymphocytes (\%) & $31.0 \pm 13.5$ & $28.6 \pm 9.1$ & 0.338 \\
NLR & $1.6(0.1-10.7)$ & $2.0(1.0-6.0)$ & 0.273 \\
PLR & $100.6(11.5-625.0)$ & $113.5(60.2-334.0)$ & 0.201 \\
Hospitalization duration (days) & $13.2 \pm 2.5$ & N/A & \\
\hline
\end{tabular}

Data are presented as median (range) (min-max) or mean \pm SD.

Abbreviations: CCHF: Crimean Congo hemorrhagic fever; M: male; F: female; WBC: white blood cell counts; MPV: mean platelet volume; NLR: neutrophil-to-lymphocyte ratio; PLR: platelet- to-lymphocyte ratio, N7A: not applicable.

\section{Pearson correlation analysis}

A negative correlation was found between the duration of hospitalization and WBC counts $(r=-0.784$, $p<0.001)$ and platelet numbers $(r=-0.838, p<0.001)$. Hospitalization duration was also positively correlated with MPV $(r=0.606, p<0.001)$, creatinine $(r=0.407, p<0.001)$, glucose $(r=0.270, p=0.011)$, LDH $(r=0.411, p<0.001)$, CPK $(r=0.291, p=0.006)$, total bilirubin $(r=0.367, p<0.001)$, BUN $(r=0.266$, $p=0.013)$, AST $(r=0.069, p=0.012), \operatorname{ALT}(r=0.396$, $p<0.001)$, CRP $(r=0.327, p=0.002)$, PT $(r=0.599$, $p<0.001)$, and aPTT $(r=0.541, p<0.001)$ levels.

\section{Mean Value Analysis (MVA)}

The correlation between the length of hospital stay and MPV and the other parameters was evaluated. WBC counts (OR $0.001,95 \% \mathrm{Cl} 0.001-0.000$, $\mathrm{p}<0.001)$, platelet numbers (OR $-0.028,95 \% \mathrm{Cl}$ $-0.046--0.011, p=0.002)$, PT (OR $0.858,95 \% \mathrm{Cl}$ $0.185-1.530, p=0.013)$, and levels of creatinine (OR $2.867,95 \% \mathrm{Cl} 0.235-5.498, \mathrm{p}=0.033$ ), and FPG (OR $0.041,95 \% \mathrm{Cl} 0.001-0.080, \mathrm{P}=0.044$ ) were found to be predictive for hospital stay. However, there was no significant correlation between MPV or NLR and duration of hospitalization (Table 3). 
Table 2. Results of Biochemical parameters for the 2 groups

\begin{tabular}{lccc}
\hline & CCHF & Control & p value \\
\hline FPG $(\mathrm{mg} / \mathrm{dL})$ & $108.9 \pm 24.7$ & $99.0 \pm 10.1$ & 0.013 \\
BUN $(\mathrm{mg} / \mathrm{dL})$ & $39(21-68)$ & $33(20-40)$ & 0.022 \\
Creatinine $(\mathrm{mg} / \mathrm{dL})$ & $1.1(0.4-2.0)$ & $0.7(0-1.5)$ & 0.001 \\
AST (IU/L) & $91(17-2241)$ & $20(13-52)$ & 0.001 \\
ALT (IU/L) & $64(16-645)$ & $17(7-45)$ & 0.001 \\
GGT (IU/L) & $38(6-515)$ & $33(15-73)$ & 0.571 \\
LDH (IU/L) & $422(152-2434)$ & $191(126-259)$ & 0.001 \\
CPK (IU/L) & $220(51-4482)$ & $74(38-108)$ & 0.001 \\
Tbil (mg/dL) & $1.3(0.3-3.0)$ & $0.8(0.4-1.6)$ & 0.001 \\
Dbil (mg/dL) & $0.3(0-1.6)$ & $0.4(0.2-0.7)$ & 0.008 \\
PT (sec) & $15.9(13.4-30.7)$ & $13.0(11.1-14.8)$ & 0.001 \\
aPTT (sec) & $38(30.0-59.7)$ & $30(25-37)$ & 0.001 \\
INR & $1.2(1.0-2.7)$ & $1.0(0.8-1.2)$ & 0.001 \\
ESR (mm/hr) & $20.5 \pm 14.9$ & $16.8 \pm 13.5$ & 0.235 \\
CRP (mg/dL) & $0.9(0.3-12.6)$ & $0.4(0.2-2.7)$ & 0.007 \\
\hline
\end{tabular}

Table 3. Relationship between hospitalization duration and confounding variables by multiple logistic regression analysis

\begin{tabular}{lccc}
\hline Independent variables & OR & $95 \% \mathrm{Cl}$ & p value \\
\hline Age & -0.003 & $0.060-0.055$ & 0.928 \\
WBC & -0.001 & $-0.001-0.000$ & 0.001 \\
Hb & -0.065 & $-0.534-0.404$ & 0.783 \\
Platelet & -0.028 & $-0.046-0.011$ & 0.002 \\
MPV & 0.247 & $-0.834-1.328$ & 0.650 \\
NLR & 0.037 & $-0.443-0.518$ & 0.877 \\
PLR & 0.013 & $-0.007-0.034$ & 0.197 \\
PT & 0.858 & $0.185-1.530$ & 0.013 \\
aPTT & -0.055 & $-0.205-0.094$ & 0.498 \\
FPG & 0.041 & $0.001-0.080$ & 0.044 \\
BUN & -0.011 & $-0.085-0.064$ & 0.777 \\
Creatinine & 2.867 & $0.235-5.498$ & 0.033 \\
Tbil & 0.664 & $-0.559-1.886$ & 0.282 \\
AST & -0.003 & $-0.013-0.007$ & 0.567 \\
ALT & 0.012 & $-0.009-0.033$ & 0.257 \\
LDH & -0.004 & $-0.012-0.004$ & 0.292 \\
CRP & -0.086 & $-0.414-0.242$ & 0.603 \\
CPK & 0.001 & $-0.001-0.003$ & 0.334 \\
\hline
\end{tabular}

Range) (min-max) or mean \pm SD.

Abbreviations CCHF, Crimean Congo hemorrhagic fever; FPG, fasting plasma glucose; BUN, blood urea nitrogen; AST, aspartate aminotransferase; ALT, alanine aminotransferase; GGT, gamma glutamyl transferase; $\mathrm{LDH}$, lactate dehydrogenase; CPK, creatine phosphokinase; Tbil, total bilirubin; Dbil:, direct bilirubin; PT, prothrombin time; aPTT:, activated partial thromboplastin time; ESR, erythrocyte sedimentation rate; CRP, $\mathrm{C}$ reactive protein

Abbreviations: WBC white blood cell counts; MPV, mean platelet volume; NLR, neutrophil-to-lymphocyte ratio; PLR, platelet- tolymphocyte ratio; $\mathrm{PT}$, prothrombin time; aPTT, activated partial thromboplastin time; FPG, fasting plasma glucose; BUN, blood urea nitrogen; Tbil, total bilirubin; AST, aspartate aminotransferase; ALT, alanine aminotransferase; LDH, lactate dehydrogenase; CRP, C reactive protein; CPK, creatine phosphokinase 


\section{DISCUSSION}

This study showed that while the levels of MPV, PT, aPTT, creatinine, AST, ALT, CRP, LDH, and total bilirubin were significantly higher, the counts of platelet and WBC were significantly lower in patients with $\mathrm{CCHF}$ than those of the control group. There was a positive correlation between hospitalization duration and MPV, coagulation parameters, $\mathrm{LDH}$ and other biochemical parameters; while there was a negative correlation between hospitalization duration and platelet numbers. To determine the independent predictors of hospitalization duration, MVA was carried out. Decreased platelet and WBC counts, along with increased PT and glucose were also found to be predictors of hospitalization duration. Interestingly, while MPV levels were higher in patients, this was not a predictor for hospitalization duration. In a previous study, MPV levels were reported to be higher in patients with CCHF than those of the control group. It was found to be a predictor for both hospitalization duration and mortality. ${ }^{6}$ In our study, the cases were relatively mild in severity grading and there were no mortalities. There were only five cases with gastrointestinal bleeding and one case with skin ecchymosis.

Previous studies reported that patients with $\mathrm{CCHF}$ could be discharged after their platelet numbers rise above 109/L. ${ }^{11}$ In addition to these reported data, our study shows that leucocyte and platelet numbers, as well as glucose and creatinine levels, and blood PT could be predictors of hospitalization duration. Hemophagocytosis plays a role in decreasing WBC and platelet levels in patients with CCHF. During the viral infection, pro-inflammatory cytokines are released excessively from macrophages and T-lymphocytes. ${ }^{12}$ These cytokines contribute to the development of pancytopenia, which causes endothelial damage and reactive hemophagocytosis. Proinflammatory cytokines enhance oxidative stress and cause the release of large and active platelets from the bone marrow. ${ }^{13}$ Increased oxidative stress has been reported in patients with CCHF. ${ }^{14}$ In addition, IL-6 directly stimulates megakaryopoiesis. ${ }^{15}$ On the other hand, the main target of the virus is the endothelium whose dysfunction activates platelets, resulting in thrombosis. ${ }^{16}$ The increased MPV levels observed in this study in patients could be related to the release of pro-inflammatory cytokines. There was no correlation between the length of hospitalization and MPV levels. Because intense hemophagocytosis occurs during $\mathrm{CCHF}$, the release of large and active thrombocytes from the bone marrow to peripheral blood could increase. However if these thrombocytes undergo rapid hemophagocytosis, MPV levels may not increase. On the other hand, increased TNF- $\alpha$ and IFN-y could cause thrombocytopenia, thus inhibiting thrombocytogenesis in the bone marrow. ${ }^{16}$ Elevated pro-inflammatory cytokines not only cause severe thrombocytopenia by hemophagocytosis and direct suppression of haemopoiesis but also release active thrombocytes in the periphery by increasing oxidative stress and the direct effect of IL-6.

Bicytopenia and pancytopenia could also be seen in patients with CCHF. In severe cases, neutropenia and severe thrombocytopenia are also frequently encountered. NLR has been reported as a prognostic factor in a large number of disorders. ${ }^{17}$ NLR is also a well-known predictor of atherosclerosis. ${ }^{18}$ In our study, the NLR of patients was similar to that of the control group. Although WBC count was significantly lower in patients, their NLR was unchanged. In previous studies, cytotoxic T-lymphocyte levels were found to be higher in terminal cases. ${ }^{19}$ However, no overall increase in lymphocyte levels was found due to the decrease in other lymphocyte subsets. In addition, the PLR levels of the patients were similar those of the control group. There was no correlation between hospitalization duration and MPV, NLR or PLR. However, we did find a significant correlation between hospitalization duration and platelet and WBC levels. Patients with $\mathrm{CCHF}$ require frequent thrombocyte and leucocyte suspensions. If this support is not provided in time, both hospitalization duration and the risk of mortality increase. Platelet and WBC levels are significant prognostic factors in contrast to MPV. Pancytopenia stemming mainly from hemophagocytosis affects both cell types. In our study, both study groups had similar levels of hemoglobin indicating lack of prominent bleeding in patients.

CRP is a valuable marker for the severity of systemic inflammation. In this study, the CRP levels of the patients were significantly higher than those of the control group. CRP was unrelated to hospitalization duration in this study. The PT, creatinine and glucose levels of patients were strong prognostic indicators for hospitalization duration. During viral infection, intense TNF- $\alpha$ and IFN- $\gamma$ could cause vascular dysfunction, disseminated intravascular coagulation, and hepatic and renal failure. ${ }^{3}$ Therefore, the levels of PT and creatinine were confirmed as prognostic factors, in line with previous studies..$^{20}$ This study found a strong correlation between glucose levels and hospital stay. Elevation of pro-inflammatory cytokines could result in an increase in 
blood glucose levels that negatively affect PPARY (peroxisome proliferator-activated receptor gamma) and cause pancreatic beta-cell destruction. ${ }^{21}$ Hyperglycemia could increase the level of glycosylatedend-products and lead to insulin resistance. As a result of both situations, pre-existing endothelial damage could increase further. In addition, hyperglycemia could lead to susceptibility to infection. Thus, the dysregulation of blood glucose process could result in longer hospitalization durations. In our study, the LDH and CPK levels of patients were significantly higher. However, we found that LDH and CPK were not good prognostic factors for predicting hospitalization duration. Both LDH and CPK levels increase due to cytolysis. Since the levels of $\mathrm{LDH}$ and CPK increase throughout the course of the disease, they could serve as indicators disease progression following tick bites.

In conclusion, hemophagocytosis occurs in patients with CCHF due to excessive pro-inflammatory cytokines. Thus, WBC and platelet numbers decrease rapidly and significantly, while young and active platelets are released to the periphery, whose MPV levels increase. However, MPV levels are not adequate for evaluating hospitalization duration. The NLR and PLR of patients with CCHF are similar to those of the control group. Decreased WBC and platelet counts, accompanied by increase in PT, creatinine and glucose levels are independent strong predictors of hospitalization duration. Elevated levels of PT, creatinine, and glucose together with decrease in WBC and platelets lead to protracted hospital stays. Therefore, close follow up of these parameters are warranted.

\section{Conflict of interest}

The authors report no conflict of interest.

\section{REFERENCES}

1. Oncü S. Crimean-Congo hemorrhagic fever: an overview. Virol Sin 2013;28:193-201.

2. Ftika L, Maltezou HC. Viral haemorrhagic fevers in healthcare settings. J Hosp Infect 2013;83:185-192.

3. Saksida A, Duh D, Wraber B, et al. Interacting roles of immune mechanisms and viral load in the pathogenesis of crimean-congo hemorrhagic fever. Clin Vaccine Immunol 2010;17:1086-1093.

4. Cure MC, Cure E, Kirbas A, et al. The effects of Gilbert's syndrome on the mean platelet volume and other hematological parameters. Blood Coagul Fibrinolysis 2013;24:484-488.
5. Han JS, Park TS, Cho SY, et al. Increased mean platelet volume and mean platelet volume/platelet count ratio in Korean patients with deep vein thrombosis. Platelets 2013;24:590593.

6. Ekiz F, Gürbüz Y, Basar Ö, et al. Mean platelet volume in the diagnosis and prognosis of Crimean-Congo hemorrhagic fever. Clin Appl Thromb Hemost 2013;19:441-444.

7. Okyay GU, Inal S, Oneç K, et al. Neutrophil to lymphocyte ratio in evaluation of inflammation in patients with chronic kidney disease. Ren Fail 2013;35:29-36.

8. Turkmen K, Erdur FM, Ozcicek F, et al. Platelet-to-lymphocyte ratio better predicts inflammation than neutrophil-to-lymphocyte ratio in end-stage renal disease patients. Hemodial Int 2013;17:391-396.

9. Erduran E, Cakir M. Reactive hemophagocytic lymphohistiocytosis and Crimean-Congo hemorrhagic fever. Int $\mathrm{J}$ Infect Dis 2010;14:349-350.

10. Swanepoel R, Gill DE, Shepherd AJ, et al. The clinical pathology of Crimean-Congo hemorrhagic fever. Rev Infect Dis 1989;11:794-800.

11. Leblebicioglu $H$, Bodur $H$, Dokuzoguz $B$, et al. Case management and supportive treatment for patients with Crimean-Congo hemorrhagic fever. Vector Borne Zoonotic Dis 2012;12:805-811.

12. Bıçakçı Z, Tavil B, Tezer H, Olcay L. Hemophagocytosis in a case with Crimean-Congo hemorrhagic fever and an overview of possible pathogenesis with current evidence. Turk J Pediatr 2013;55:344-348.

13. Cumhur Cure M, Cure E, Yuce S, et al. Mean Platelet Volume and Vitamin D Level. Ann Lab Med 2014;34:98-103.

14. Karadag-Oncel E, Erel O, Ozsurekci $Y$, et al. Plasma oxidative stress and total thiol levels in crimean-congo hemorrhagic Fever. Jpn J Infect Dis 2014;67:22-26.

15. Sui $X$, Tsuji K, Ebihara $Y$, et al. Soluble interleukin-6 (IL-6) receptor with IL-6 stimulates megakaryopoiesis from human CD34(+) cells through glycoprotein (gp)130 signaling. Blood 1999;93:2525-2532.

16. Pehlivan M, Okan V, Sever T, et al. Investigation of TNFalpha, TGF-beta 1, IL-10, IL-6, IFN-gamma, MBL, GPIA, and IL1A gene polymorphisms in patients with idiopathic thrombocytopenic purpura. Platelets 2011;22:588-595.

17. Troppan K, Deutsch A, Gerger A, et al. The derived neutrophil to lymphocyte ratio is an independent prognostic factor in patients with diffuse large B-cell lymphoma. $\mathrm{Br} \mathrm{J}$ Cancer 2014;110:369-374.

18. Kaya H, Ertaş F, İslamoğlu $Y$, et al. Association between neutrophil to lymphocyte ratio and severity of coronary artery disease. Clin Appl Thromb Hemost 2014;20:50-54.

19. Akinci E, Yilmaz M, Bodur $\mathrm{H}$, et al. Analysis of lymphocyte subgroups in Crimean-Congo hemorrhagic fever. Int J Infect Dis 2009;13:560-563.

20. Tasdelen Fisgin N, Tanyel E, Doganci L, Tulek N. Risk factors for fatality in patients with Crimean-Congo haemorrhagic fever. Trop Doct 2009;39:158-160.

21. Eguchi $\mathrm{K}$, Manabe I. Macrophages and islet inflammation in type 2 diabetes. Diabetes Obes Metab 2013;15:152-158. 